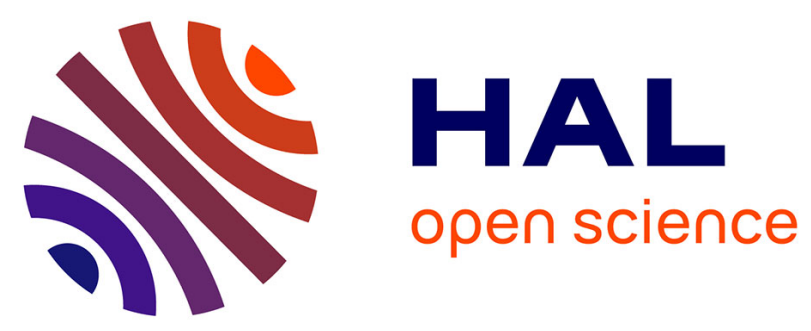

\title{
N2 Reduction: Interfacing the Enzyme Nitrogenase with Electrodes
}

Vincent Fourmond, Christophe Léger

\section{To cite this version:}

Vincent Fourmond, Christophe Léger. N2 Reduction: Interfacing the Enzyme Nitrogenase with Electrodes. Angewandte Chemie International Edition, 2017, 56 (16), pp.4388 - 4390. 10.1002/anie.201701179 . hal-01514839

\section{HAL Id: hal-01514839 \\ https://hal-amu.archives-ouvertes.fr/hal-01514839}

Submitted on 23 Apr 2018

HAL is a multi-disciplinary open access archive for the deposit and dissemination of scientific research documents, whether they are published or not. The documents may come from teaching and research institutions in France or abroad, or from public or private research centers.
L'archive ouverte pluridisciplinaire HAL, est destinée au dépôt et à la diffusion de documents scientifiques de niveau recherche, publiés ou non, émanant des établissements d'enseignement et de recherche français ou étrangers, des laboratoires publics ou privés. 


\section{$\mathrm{N}_{2}$ reduction: interfacing the enzyme nitrogenase with electrodes}

\section{Vincent Fourmond and Christophe Léger*}

Two processes contribute equally to the humanity's colossal needs for fixed forms of nitrogen: the high-temperature, highpressure Haber-Bosch process, ${ }^{[1]}$ and the biological reduction of $\mathrm{N}_{2}$ by the enzyme nitrogenase, which is found only in a selected group of microorganisms and played a critical role during the early expansion of microbial life. ${ }^{[2]}$ Nitrogenases accomplish the great feat of activating $\mathrm{N}_{2}$ under mild conditions, using the energy that is supplied in vivo by the hydrolysis of adenosine 5'triphosphate (ATP).

Milton, Minteer and coworkers recently showed that this enzyme can receive from methyl viologen, and ultimately electrodes, the electrons that it uses to reduce $\mathrm{N}_{2}{ }^{\left[{ }^{3 a]}\right.}$ In an earlier work, they used cobaltocene to mediate electrons between an electrode and the $\mathrm{MoFe}$ protein of nitrogenase, but no $\mathrm{N}_{2}$ reduction was observed. ${ }^{[3 b]}$ This new result opens the way for developing various electrochemical devices and calls for further investigations of the kinetics of the reaction of the enzyme with the versatile electron donor methyl viologen.

Nitrogenase (here we focus on the Mo-containing version) catalyses the reduction of $\mathrm{N}_{2}$ according to a reaction that is often written as:

$\mathrm{N}_{2}+8 \mathrm{e}^{-}+16 \mathrm{MgATP}+8 \mathrm{H}^{+} \Rightarrow 2 \mathrm{NH}_{3}+\mathrm{H}_{2}+16 \mathrm{MgADP}+16 \mathrm{P}_{\mathrm{i}}(1$

For each molecule of $\mathrm{N}_{2}$ that is reduced (a six-electron reaction), the enzyme needs at least 8 electrons, hydrolyzes at least 16 molecules of ATP to ADP and inorganic phosphate $(\mathrm{Pi})$ and produces at least one molecule of $\mathrm{H}_{2}$. In the absence of $\mathrm{N}_{2}$, the enzyme catalyzes hydrogen evolution according to

$$
2 \mathrm{H}^{+}+2 \mathrm{e}^{-}+4 \mathrm{MgATP} \Rightarrow \mathrm{H}_{2}+4 \mathrm{MgADP}+4 \mathrm{P}_{\mathrm{i}}(2)
$$

Nitrogenase is composed of two components termed $\mathrm{Fe}$ and MoFe proteins (fig 1), which bind and slowly dissociate during the catalytic cycle. ${ }^{[4 a]}$ The Fe protein contains the binding sites for ATP and a single [4Fe4S] redox cluster. The MoFe protein houses the $\left[\mathrm{Fe}_{7} \mathrm{~S}_{9} \mathrm{MoC}\right.$-homocitrate] cofactor or "FeMo-co", which is the active site for $\mathrm{N}_{2}$ reduction, and the $\left[\mathrm{Fe}_{8} \mathrm{~S}_{7}\right] \mathrm{P}$-cluster, which mediates electron transfer from the Fe protein to FeMo$\mathrm{co}^{[4 \mathrm{~b}]}$

The transformations among catalytic intermediates of the FeMo$\mathrm{co}$, denoted $\mathrm{E}_{0}$ to $\mathrm{E}_{8}$ (where the subscript indicates the number of electrons and protons delivered to the FeMo-co), are shown in scheme 1. Reversible $\mathrm{N}_{2}$ binding occurs at stage 3 or 4 , after the accumulation of 3 or 4 electrons and protons. The mechanism proposed by Hoffman, Dean and Seefeldt supports the obligatory release of two (expensive) reducing equivalents upon release of one $\mathrm{H}_{2}$ molecule when $\mathrm{N}_{2}$ binds. ${ }^{[5]}$ In this mechanism, the FeMo-cofactor cycles through only two formal redox levels of the metal-ion core as the first 4 electrons and protons are successively transferred to the FeMo-co, because the reducing equivalents are formally stored as pairs of metal-bound protons and hydrides, rather than on the metal ions. A similar

[a] Laboratoire de Bioénergétique et Ingénierie des Protéines, Aix Marseille Université, CNRS, UMR7281, Marseille, France E-mail: leger@imm.cnrs.fr, web: www.bip.cnrs-mrs.fr/bip06 mechanism operates in hydrogenases, the enzymes that reversibly oxidize and produce $\mathrm{H}_{2}$. At stage 4 in scheme 1 , reductive elimination of $\mathrm{H}_{2}$ produces a highly activated, doubly reduced site, where $\mathrm{N}_{2}$ binds and is subsequently hydrogenated. Other chemists have favored alternative mechanisms that use only 6 electrons. ${ }^{[6]}$

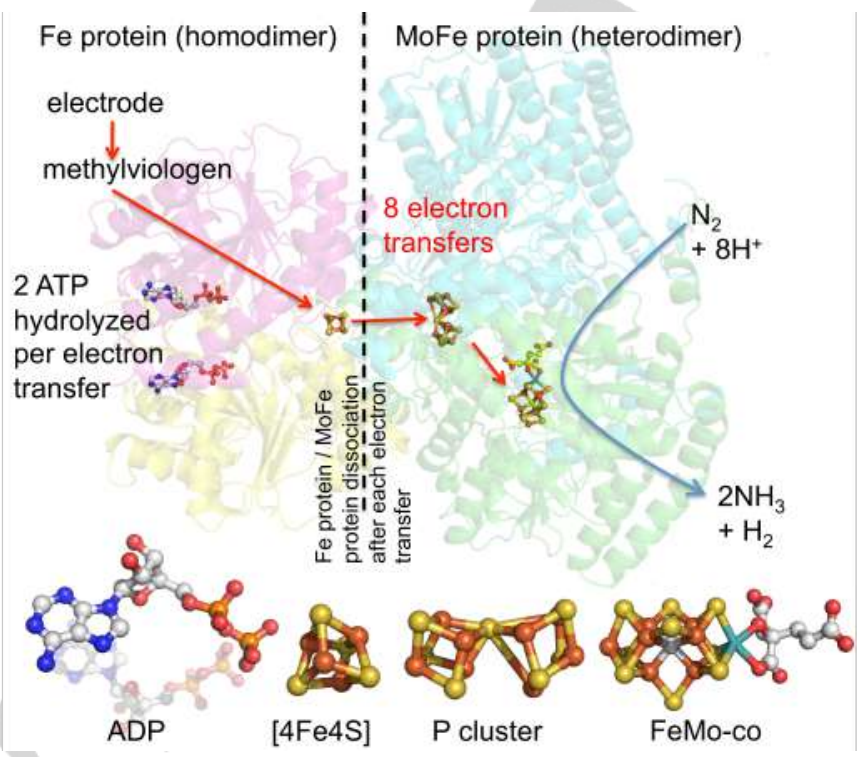

Figure 1. The structure, reaction and cofactors of the $\mathrm{Fe}$ protein / $\mathrm{MoFe}$ protein nitrogenase complex (pdb accession codes IN2C and 3U7Q). ${ }^{[4]}$

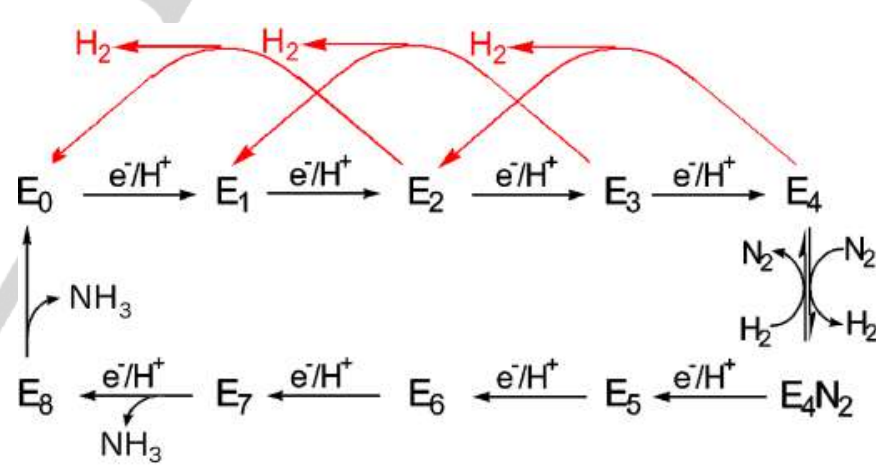

Scheme 1. Kinetic scheme depicting the sequential delivery of electrons/protons to the FeMo-co, the futile $\mathrm{H}_{2}$-production cycles (in red), the reversible binding of $\mathrm{N}_{2}$ (consistent with the hypothesis of obligatory reductive elimination of $\mathrm{H}_{2}$ discussed in ref [5]), and the release of product $\mathrm{NH}_{3}$. Adapted from figs 3 and 19 and scheme 1 in ref [5].

Hydrolysis of one mol of ATP provides about $60 \mathrm{~kJ}$ (the exact value depends on how far from equilibrium is the steady-state ATP/ADP ratio maintained by the bioenergetics metabolism; ${ }^{[7]}$ it is not, unlike sometimes stated, the standard free energy of the reaction of ATP hydrolysis). Considering the stoichiometry in eq 1 , this implies that electrons involved in a particular electron transfer step in the nitrogenase catalytic cycle may be "energized" by more than $1.2 \mathrm{~V}$ by using 2 molecules of ATP $(1.2 \mathrm{~V}=2 \times 60 \mathrm{~kJ} / \mathrm{F})$. Which step(s) exactly benefit(s) from this additional energy is an active subject of research. Both ATP binding to the $\mathrm{Fe}$ protein and $\mathrm{Fe} / \mathrm{MoFe}$ proteins association decrease the potential of the $[4 \mathrm{Fe} 4 \mathrm{~S}]$ cluster, ${ }^{[8]}$ which implies that binding is much stronger when the Fe protein is oxidized; therefore, ATP hydrolysis may just be the price to pay for forcing the dissociation of the complex. In experiments where low potential electrons are photo-generated and transferred to the 
MoFe protein to drive catalysis (resulting in either $\mathrm{H}_{2}$ evolution or $\mathrm{N}_{2}$ reduction, depending on the nature of the photosensitizer), there is no need for Fe protein or ATP. ${ }^{[9]}$

In most kinetic studies, the electrons required to reduce $\mathrm{N}_{2}$ are received by nitrogenase from the slow and complex electron donor dithionite (DT), or, less frequently, from the physiological reductants flavodoxin or ferredoxin. Here, Milton, Minteer and colleagues make a significant step forward by providing the first evidence that the non physiological electron donor methyl viologen (MV), which is often used in kinetic and electrochemical studies of other redox enzymes, can sustain $\mathrm{N}_{2}$ reduction by nitrogenase at a significant rate. ${ }^{[3 a]}$ This makes it possible to interface the enzyme with electrodes and to use it in a variety of bioelectrochemical devices, the feasibility of some of which is illustrated in the paper. Indeed, the authors demonstrated that the nitrogenase cathode can be coupled to various anodes in a fuel cell configuration, including one anode that produces electrons by the catalytic oxidation of $\mathrm{H}_{2}$ by the enzyme hydrogenase. A fuel cell was constructed that reaches an OCP of $250 \mathrm{mV}$ and delivers $20 \mu \mathrm{A} / \mathrm{cm}^{2}$ at a maximal power density of $1.4 \mu \mathrm{W} / \mathrm{cm}^{2}$.

In the experiments highlighted here, ADP is continuously rephosporylated by the sacrificial consumption of creatine phosphate. The supply of ATP will remain limiting for any practical use of nitrogenase, unless it becomes possible to couple $\mathrm{N}_{2}$ bioelectrochemical reduction to a system that regenerates ATP using the energy from e.g. light. ${ }^{[10]}$

Methyl viologen is used here for the first time as an electron donor to nitrogenase, and this electron transfer will probably be investigated in follow up studies, knowing that changing the redox partner of nitrogenase may change the rate limiting step in catalysis ${ }^{[11]}$ and the distribution of products. ${ }^{[9]}$ The authors observe that the rate of $\mathrm{N}_{2}$ reduction by $\mathrm{MV}$ is $75 \%$ of that when DT is used as reductant, and that the efficiency of the reduction (in terms of charged passed to $\mathrm{NH}_{3}$ produced) is suboptimal, in the range $25 \%$ to $60 \% .{ }^{[3 a]}$ This suggests that the enzyme wastes electrons (and ATP) to produce more $\mathrm{H}_{2}$ than just one per $\mathrm{N}_{2}$ (eq 1). According to scheme $1, \mathrm{H}_{2}$ can be released from a number of catalytic intermediates, as the FeMo-co spontaneously returns to a two-electron more oxidized state, closing a futile $\mathrm{H}_{2}$ production cycle. ${ }^{[5]}$ If the rate of reduction of the nitrogenase complex by $\mathrm{MV}$ is low, it may be that the competition between $\mathrm{H}_{2}$ evolution and ATP-dependent electron accumulation leads to the continuous reoxidation of the FeMo-co (upon $\mathrm{H}_{2}$ release) before $\mathrm{N}_{2}$ binds (scheme 1), and decreases the overall efficiency of $\mathrm{N}_{2}$ reduction. This is reminiscent of the earlier observation that not all photochemical electron donors can sustain $\mathrm{N}_{2}$ reduction. ${ }^{[9]} \mathrm{A}$ final complication with MV may be the possibility of ATP. dependent reverse electron transfer from the Fe protein in the complex back to oxidized MV. This may consume ATP and slow down the reduction of the MoFe protein, further increasing the probability of wasting reductive equivalents by $\mathrm{H}_{2}$ release. Electrons may also be lost in the non-enzymatic evolution of $\mathrm{H}_{2}$, but probably not on the carbon electrodes used by the authors.

As a final perspective, we note that a central challenge regarding the biological reduction of $\mathrm{N}_{2}$ is that both of the Fe and MoFe proteins that compose the nitrogenase enzyme are irreversibly damaged by oxygen. The former is particularly sensitive. ${ }^{[12 a]}$ Nitrogenase-based photobiological production of $\mathrm{H}_{2}$ is possible in aerobic photosynthetic microorganisms such as cyanobacteria on condition that $\mathrm{H}_{2}$ production is temporally or spatially separated from photosynthesis, and oxygen sensitivity of nitrogenase has been recognized as an obstacle for bioengineering nitrogen fixation into cereal crops. Strict anoxia will also be a requirement for using the enzyme in electrochemical cells, but the viologen mediator may come to the rescue. Indeed, there have been recent developments showing that oxygen sensitive enzymes can be protected from oxygen upon incorporation in a hydrated film of polymer bearing viologen moieties. The latter mediate electron transfer between the enzyme and the electrode, and also prevent oxygen from penetrating the film by reducing it to water. ${ }^{[12 \mathrm{~b}]}$ So far the protection has proved effective only under conditions of oxidative catalysis, but redox hydrogels can also promote reductive catalysis. The objective of using nitrogenase will further motivate the search of alternative protection mechanisms that operate under reductive conditions.

Keywords: electrocatalysis $\cdot$ nitrogenase $\cdot \mathrm{N}_{2}$ reduction

[1] a) D. E. Canfield, A. N. Glazer, P. G. Falkowski, Science 2010, 330 192-196. b) J. W. Erisman, M. A. Sutton, J. Galloway, Z. Klimont, W. Winiwarter, Nature Geoscience 2008, 1, 636-639.

[2] J. Raymond, Mol. Biol. Evol. 2003, 21, 541-554.

[3] a) R. D. Milton, R. Cai, S. Abdellaoui, D. Leech, A. L. De Lacey, M. Pita S. D. Minteer, Angew. Chem. Int. Ed. 2016, anie.201612500. b) R.D Milton, S. Abdellaoui, N. Khadka, D. R. Dean, D. Leech, L. C. Seefeldt and S. D. Minteer, Enery Environ. Sci. 2016, 9, 2550-2554

[4] (a) H. Schindelin, C. Kisker, J. L. Schlessman, J. B. Howard† \& D. C. Rees Nature 1997 387, 370-376 (b) T. Spatzal, M. Aksoyoglu, L. Zhang, S. L. A. Andrade, E. Schleicher, S. Weber, D. C. Rees, O. Einsle Science 2011 334, 940.

[5] B. M. Hoffman, D. Lukoyanov, Z.-Y. Yang, D. R. Dean, L. C. Seefeldt, Chem. Rev. 2014, 114, 4041-4062.

[6] a) J. C. Peters, M. P. Mehn, Activation of Small Molecules 2006, 81119. b) I. Dance, Chemical Communications 2013, 49, 10893.

[7] D. G. Nicholls, S. J. Ferguson, Bioenergetics, Academic Press, Elsevier, Amsterdam, 2013.

[8] W. N. Lanzilotta, L. C. Seefeldt, Biochemistry 1997, 36, 12976-12983.

[9] a) K. A. Brown, D. F. Harris, M. B. Wilker, A. Rasmussen, N. Khadka, H. Hamby, S. Keable, G. Dukovic, J. W. Peters, L. C. Seefeldt, et al., Science 2016, 352, 448-450. b) L. E. Roth, J. C. Nguyen, F. A. Tezcan, J. Am. Chem. Soc. 2010, 132, 13672-13674.

[10] a) P. Richard, B. Pitard, J.-L. Rigaud, J. Biol. Chem. 1995, 270, 2157121578. b) H.-J. Choi, C. D. Montemagno, Nano Letters 2005, 5, 25382542.

[11] Z.-Y. Yang, R. Ledbetter, S. Shaw, N. Pence, M. TokminaLukaszewska, B. Eilers, Q. Guo, N. Pokhrel, V. L. Cash, D. R. Dean, et al., Biochemistry 2016, 55, 3625-3635.

[12] a) J. Schlesier, M. Rohde, S. Gerhardt, O. Einsle, J. Am. Chem. Soc. 2016, 138, 239-247. b) V. Fourmond, S. Stapf, H. Li, D. Buesen, J. Birrell, O. Rüdiger, W. Lubitz, W. Schuhmann, N. Plumeré, C. Léger, J. Am. Chem. Soc. 2015, 137, 5494-5505. 
Entry for the Table of Contents (Please choose one layout)

Layout 1:

\section{HIGHLIGHT}

Milton, Minteer and coworkers report the first evidence for the bioelectrochemical reduction of $\mathrm{N}_{2}$ to ammonia by nitrogenase. This complex enzyme could be "wired" to an electrode by using the soluble mediator methyl viologen; this very simple approach makes it possible to develop a variety of biotechnological devices.
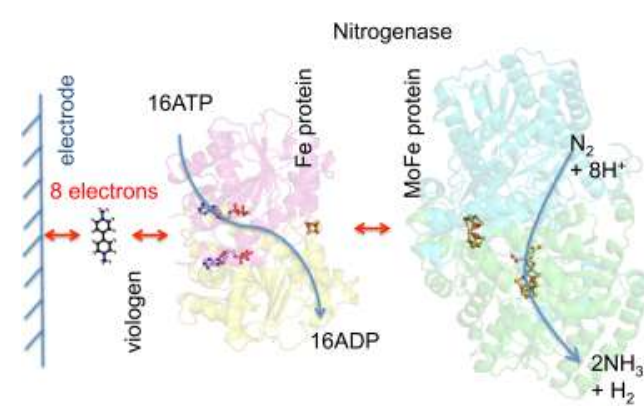

Vincent Fourmond, Christophe Léger*

Page No. - Page No.

$\mathrm{N}_{2}$ reduction: interfacing the enzyme nitrogenase with electrodes 